\title{
Status of FeCrAl ODS Irradiations in the High Flux Isotope Reactor
}

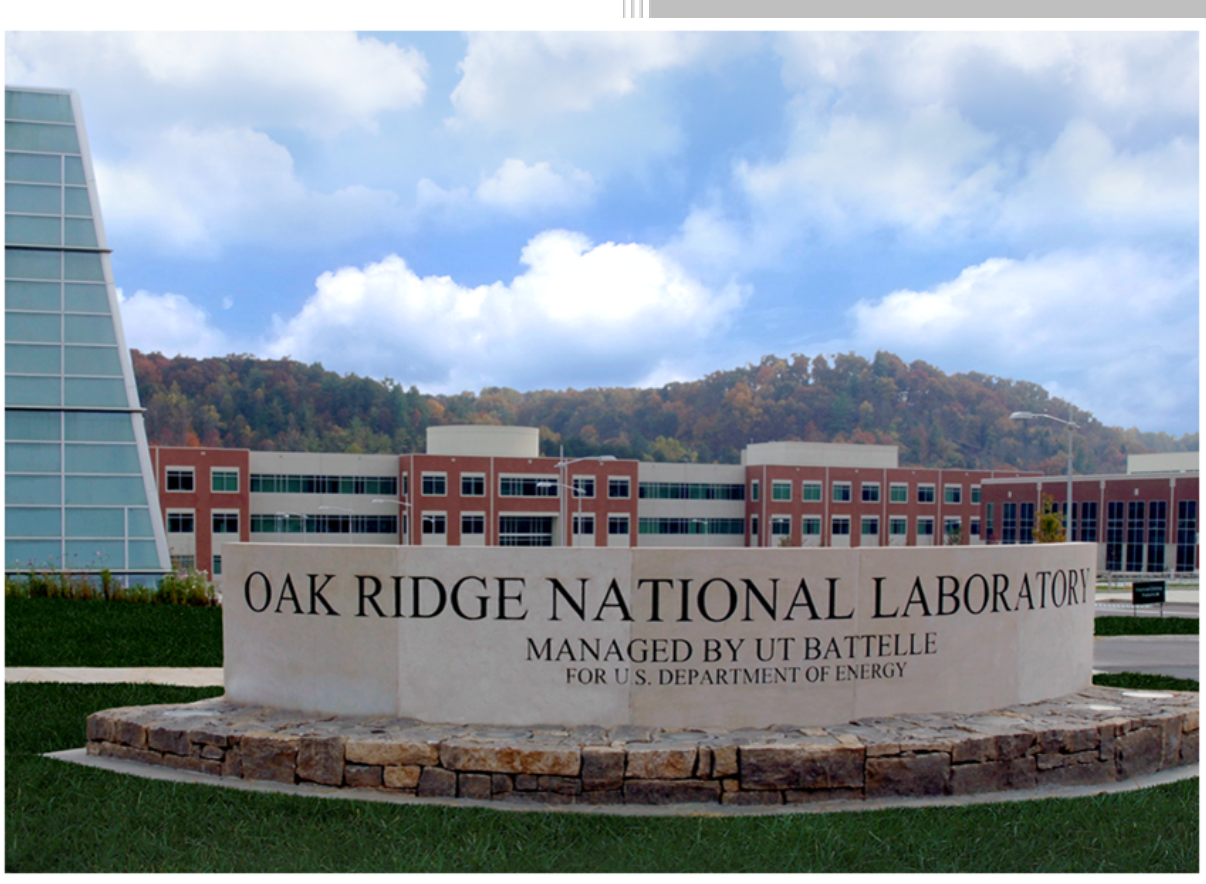

Kevin G. Field

Richard H. Howard

Approved for public release. Distribution is unlimited.

August 19, 2016 


\section{DOCUMENT AVAILABILITY}

Reports produced after January 1, 1996, are generally available free via US Department of Energy (DOE) SciTech Connect.

Website http://www.osti.gov/scitech/

Reports produced before January 1, 1996, may be purchased by members of the public from the following source:

National Technical Information Service

5285 Port Royal Road

Springfield, VA 22161

Telephone 703-605-6000 (1-800-553-6847)

TDD 703-487-4639

Fax 703-605-6900

E-mail info@ntis.gov

Website http://www.ntis.gov/help/ordermethods.aspx

Reports are available to DOE employees, DOE contractors, Energy Technology Data Exchange representatives, and International Nuclear Information System representatives from the following source:

Office of Scientific and Technical Information

PO Box 62

Oak Ridge, TN 37831

Telephone 865-576-8401

Fax 865-576-5728

E-mail reports@osti.gov

Website http://www.osti.gov/contact.html

This report was prepared as an account of work sponsored by an agency of the United States Government. Neither the United States Government nor any agency thereof, nor any of their employees, makes any warranty, express or implied, or assumes any legal liability or responsibility for the accuracy, completeness, or usefulness of any information, apparatus, product, or process disclosed, or represents that its use would not infringe privately owned rights. Reference herein to any specific commercial product, process, or service by trade name, trademark, manufacturer, or otherwise, does not necessarily constitute or imply its endorsement, recommendation, or favoring by the United States Government or any agency thereof. The views and opinions of authors expressed herein do not necessarily state or reflect those of the United States Government or any agency thereof. 
Fuel Cycle Research and Development (FCRD)

\section{Status of FeCrAl ODS Irradiation in the High Flux Isotope Reactor}

Kevin G. Field and Richard H. Howard

Date Published: August 19, 2016

Prepared by

OAK RIDGE NATIONAL LABORATORY

Oak Ridge, TN 37831-6283

managed by

UT-BATTELLE, LLC

for the

US DEPARTMENT OF ENERGY

under contract DE-AC05-00OR22725 



\section{CONTENTS}

Page

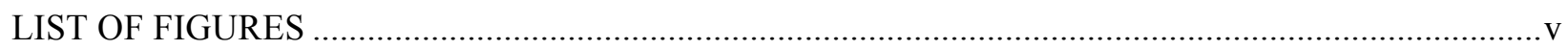

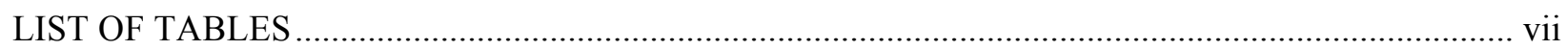

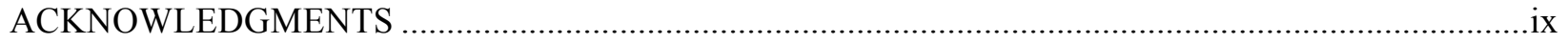

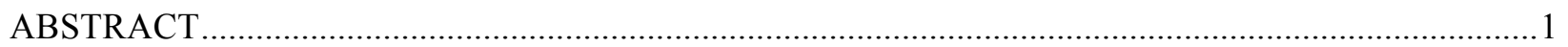

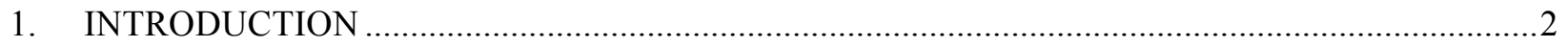

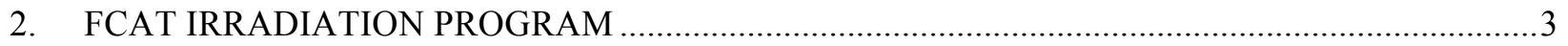

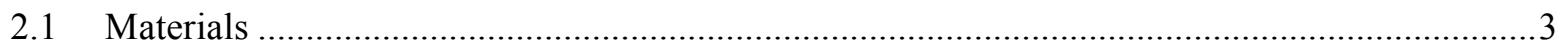

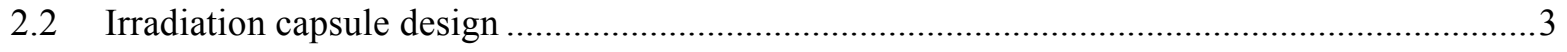

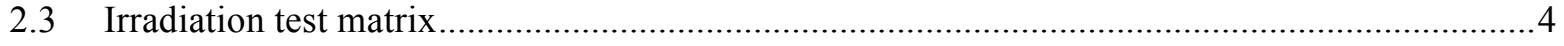

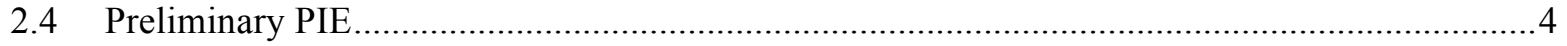

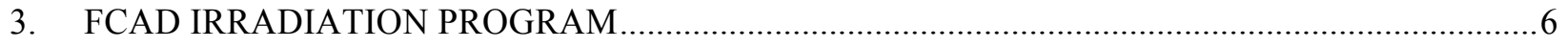

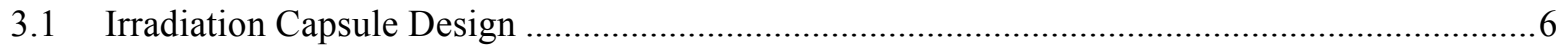

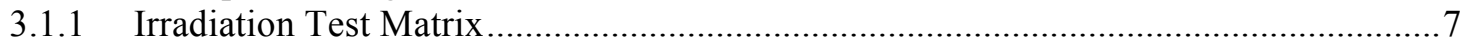

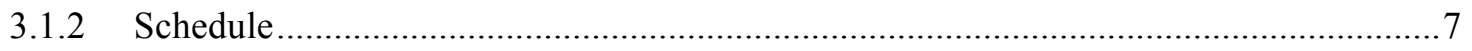

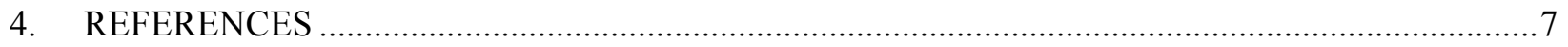





\section{LIST OF FIGURES}

Figure 1: Predicted specimen temperature contours for a $330^{\circ} \mathrm{C}$ irradiation in HFIR. …......................... 4

Figure 2: Predicted thermometry temperature contours for a $330^{\circ} \mathrm{C}$ irradiation in HFIR ......................... 4

Figure 3: Plots showing representative stress-strain curves for the 125YF alloy after irradaition in the HFIR

Figure 4: Finalized HFIR irradiation capsule design for FCAD irradiation program. Design is identical to the FCAT irradiation capsules. 



\section{LIST OF TABLES}

Table 1: Summary of FeCrAl capsule irradiation conditions. ............................................................

Table 2: Results of dilatometric analysis of SiC thermometry bars contained within irradiated

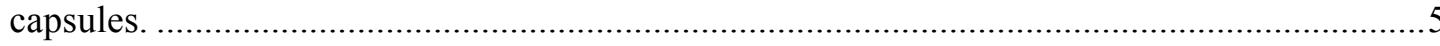

Table 3: Summary of FeCrAl capsule irradiation conditions. .............................................................. 



\section{ACKNOWLEDGMENTS}

Research was sponsored by the DOE's Office of Nuclear Energy, Advanced Fuel Campaign of the Fuel Cycle R\&D Program. Neutron irradiation of FeCrAl alloys at ORNL's HFIR user facility was sponsored by the Scientific User Facilities Division, Office of Basic Energy

Sciences, DOE. 


\begin{abstract}
FeCrAl oxide-dispersion strengthened (ODS) alloys are an attractive sub-set alloy class of the more global FeCrAl material class for nuclear applications due to their high temperature steam oxidation resistance and hypothesized enhanced radiation tolerance. A need currently exists to determine the radiation tolerance of these newly developed alloys. To address this need, a preliminary study was conducted using the High Flux Isotope Reactor (HFIR) to irradiate an early generation FeCrAl ODS alloy, 125YF. Preliminary post-irradiation examination (PIE) on these irradiated specimens have shown good radiation tolerance at elevated temperatures $\left(\geq 330^{\circ} \mathrm{C}\right)$ but possible radiation-induced hardening and embrittlement at irradiations of $200^{\circ} \mathrm{C}$ to a damage level of 1.9 displacement per atom (dpa). Building on this experience, a new series of irradiations are currently being conceptualized. This irradiation series called the FCAD irradiation program will irradiate the latest generation FeCrAl ODS and FeCr ODS alloys to significantly higher doses. These experiments will provide the necessary information to determine the mechanical performance of irradiated FeCrAl ODS alloys at light water reactor and fast reactor conditions.
\end{abstract}




\section{INTRODUCTION}

A recent interest has grown on developing novel materials deemed to have enhanced accident tolerance in light water reactor (LWR) designs. At the core of this development, are materials with increased high temperature oxidation resistance in steam environments compared to the currently deployed Zr-based components. FeCrAl-based alloys with minor Y additions are promising near-term materials for this application as they can form passivating $\mathrm{Al}_{2} \mathrm{O}_{3}$ oxide scale in steam environments up to $1450{ }^{\circ} \mathrm{C}$ while limiting the heat and hydrogen production that can exacerbate accident conditions [1,2]. Within the more global FeCrAl material class exists a subset of alloys known as oxide dispersion strengthened (ODS) FeCrAl alloys. These FeCrAl ODS alloys are characterized as having been produced via powder metallurgy techniques and contains a fine dispersion of oxide nanoclusters in the typically ferritic grain structure. FeCrAl ODS alloys are of interest as they can exhibit similar steam oxidation resistance compared to wrought $\mathrm{FeCrAl}$ alloys but have superior high temperature mechanical strength.

FeCrAl ODS alloys could also be attractive materials as their small grain sizes and fine dispersions of nanoclusters leads to increased defect density. Zinkle and Snead have shown that high sink strength materials (nominally $>10^{16} \mathrm{~m}^{-2}$ ) can exhibit increased radiation tolerance compared to lower sink strength counterparts [3]. Initial investigations into the radiation tolerance of wrought FeCrAl alloys, which have lower sink densities than FeCrAl ODS alloys, have focused on examining the compositional effects and cold-working effects on the formation of radiation-induced defect structures. These studies have shown that radiation leads to the formation of dislocation loops and radiation-enhanced precipitation of the Cr-rich $\alpha$ ' phase [4-6]. These radiation-induced/enhanced microstructural features affect the general mechanical properties of the alloys after irradiation and could be the limiting factor of the component made from a wrought FeCrAl alloy.

It is hypothesized that similar results to those presented by Zinkle and Snead can be achieved using FeCrAl ODS alloys, and the radiation tolerance, and hence the operation lifetime can be greatly increased for this material class by using ODS material. A series of neutron radiation exposures followed by post-irradiation examination (PIE) is currently on-going to test this hypothesis. Preliminary work included the irradiation of $125 \mathrm{YF}$, an FeCrAl ODS variant, alongside wrought FeCrAl alloys using the High Flux Isotope Reactor (HFIR) at Oak Ridge National Laboratory (ORNL). This irradiation series is deemed the FCAT (Fe-Cr-Al-Tensile) irradiation program. The irradiation program includes the irradiation of sub-sized SS-J2 tensile specimens to doses of $2 \mathrm{dpa}, 8 \mathrm{dpa}$, and $16 \mathrm{dpa}$ at temperatures of $200^{\circ} \mathrm{C}, 330^{\circ} \mathrm{C}$, and $550^{\circ} \mathrm{C}$. The lowest doses irradiation capsules have recently become available for PIE while the higher doses samples are awaiting insertion in the HFIR for irradiation.

A new series of irradiation capsules are currently being designed and will be fabricated to test a greater range of $\mathrm{FeCrAl}$ ODS and $\mathrm{FeCr}$ ODS alloys at elevated temperatures and doses. This irradiation series is deemed the FCAD irradiation series. It is anticipated that these irradiation capsules will be irradiated to $2 \mathrm{dpa}, 16 \mathrm{dpa}$, and $50+\mathrm{dpa}$ at temperatures of $330^{\circ} \mathrm{C}$ and $550^{\circ} \mathrm{C}$ within the HFIR at ORNL. The objective of this report is to summarize the initial findings based on preliminary PIE of the FCAT irradiation program in respect to the ODS alloy and provide insight into the test matrix and designs of the FCAD irradiation program. 


\section{FCAT IRRADIATION PROGRAM}

\subsection{Materials}

The FCAT irradiation program [7] included irradiation of 125YF, a first generation FeCrAl ODS alloy developed by ORNL. The alloy was produced from 12 wt.\% Cr, 5 wt.\% Al and balance Fe gas atomized powder. The powder size ranged from $45 \mu \mathrm{m}$ to $150 \mu \mathrm{m}$ before ball milling for $40 \mathrm{~h}$ in an Ar atmosphere in a Zoz CM08 Simoloyer. Additionally, $\mathrm{Y}_{2} \mathrm{O}_{3}$ and $\mathrm{FeO}$ powder were added to the ball mill. A 10:1 ball-to-charge ratio was used. Ball milled powder was degassed at $300^{\circ} \mathrm{C}$ for $24 \mathrm{~h}$ in a mild steel extrusion can. After degassing, the powder and can was sealed, heated for $1 \mathrm{~h}$ at $950^{\circ} \mathrm{C}$ and then extruded at $950^{\circ} \mathrm{C}$.

The resulting consolidated alloy had a composition of 83 wt.\% Fe, 11.67 wt.\% Cr, 4.9 wt.\% Al, 0.01 wt.\% Ti, 0.19 wt.\% Y, 200 ppm C, 202 ppm N, 1920 ppm O, and 30 ppm S. Grain sizes were maintained near $0.4-0.5 \mu \mathrm{m}$ with an average grain aspect ratio of 1.08. Full details on the alloy can be found elsewhere [8]. SS-J2 tensile specimens were manufactured from the extruded feedstock using electric discharge machining (EDM). EDM burn layers were mechanically removed when possible to limit the effect of these layers on subsequent mechanical tests. Individual samples were laser engraved with unique identifiers allowing tracking through the build, irradiation, and PIE processes.

\subsection{Irradiation capsule design}

Irradiation capsules which house both SS-J2 type and newly developed SS-2E type tensile specimens were developed for use within ORNL's HFIR [7]. Two SS-J2 specimens of the $125 \mathrm{YF}$ alloy were loaded in each irradiation capsule. The remaining positions within the capsule were filled with wrought $\mathrm{FeCrAl}$ alloys. Capsules also include passive $\mathrm{SiC}$ thermometry. These $\mathrm{SiC}$ specimens are used as they can validate the modeled target irradiation temperatures have been met by using post-irradiation dilatometry techniques [9]. Specimen temperatures were controlled by changing the radial gas gap between the sub-assembly and outer housing of the irradiation capsule. He gas was used as the fill gas, no temperature control was completed using varying gas compositions.

Determination of the radial gas gap and the irradiation capsule operating temperature was calculated using an ANSYS finite element analysis (FEA) design. A 3D model was completed as it provides the greatest insight into the thermal gradients within the design during irradiation. An example of the thermal gradients in 4 stacks of $3 \mathrm{SS}-\mathrm{J} 2$ tensile specimens within the FCAT irradiation design is given in Figure 1. Figure 2 shows the predicted temperature contours of the $\mathrm{SiC}$ passive thermometry in the same capsule. Note the $\mathrm{SiC}$ bulk temperatures are markedly higher than the specimens, which is due to the thermometry being oriented within the specimens and radially closer to the assembly center. Capsule outer housing material varied depending on nominal target irradiation temperature. Lower irradiation temperatures (typically $<450^{\circ} \mathrm{C}$ ) used Al 6061-T6 while higher irradiation temperature capsules used Mo-based alloys. 


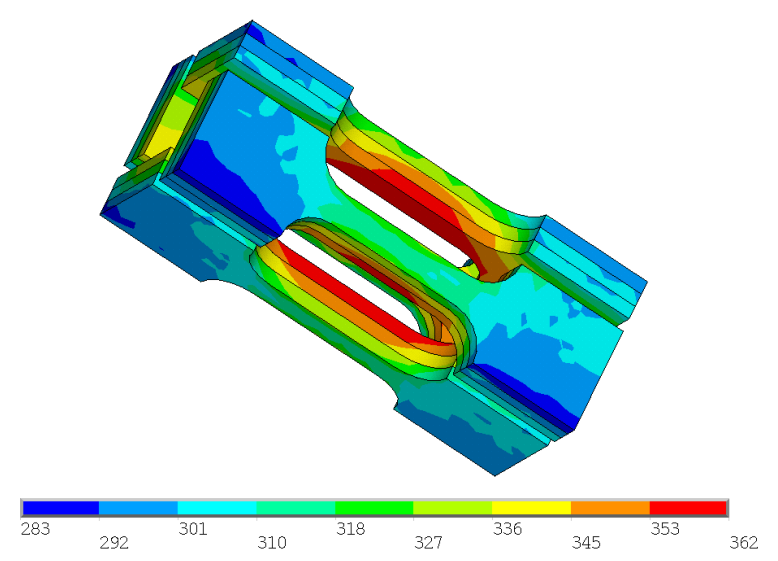

Figure 1: Predicted specimen temperature contours for a $330^{\circ} \mathrm{C}$ irradiation in HFIR.

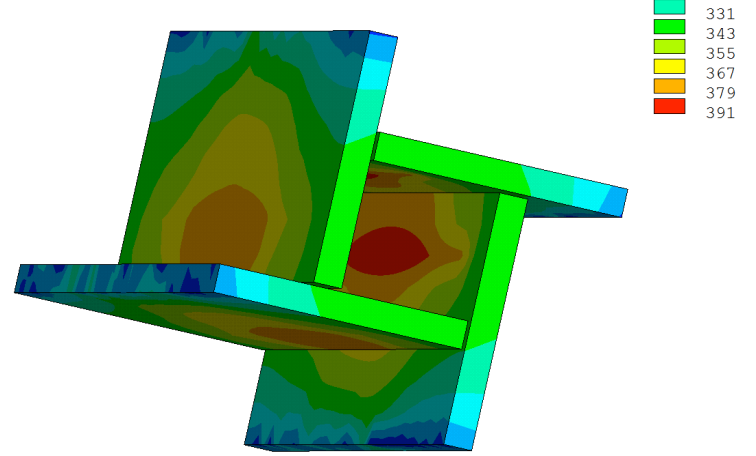

Figure 2: Predicted thermometry temperature contours for a $330^{\circ} \mathrm{C}$ irradiation in HFIR.

\subsection{Irradiation test matrix}

The FCAT irradiations were designed to investigate the contributions of composition, microstructure, irradiation dose, and irradiation temperature on the radiation tolerance of wrought and ODS FeCrAl alloys. To accomplish this task, 3 damage dose levels at 2 dpa, 8 dpa, and $16 \mathrm{dpa}$ and temperatures at $200^{\circ} \mathrm{C}, 330^{\circ} \mathrm{C}$ and $550^{\circ} \mathrm{C}$ were selected. This resulted in a total of nine different irradiation capsules being designed, built, and irradiated. Central axial positions were selected for each irradiation capsule to minimize axial thermal gradients which could lead to difficulties in interrupting PIE results. A summary of the FCAT irradiation test matrix is provided in Table 1.

Table 1: Summary of FeCrAl capsule irradiation conditions.

\begin{tabular}{|c|c|c|c|c|c|c|}
\hline Capsule ID & $\begin{array}{l}\text { Exposure } \\
\text { Time } \\
\text { (hrs) }\end{array}$ & 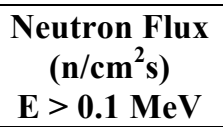 & 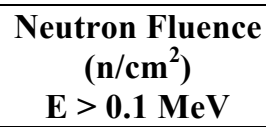 & $\begin{array}{c}\text { Dose Rate } \\
\text { (dpa/s) }\end{array}$ & $\begin{array}{l}\text { Dose } \\
\text { (dpa) }\end{array}$ & $\begin{array}{c}\text { Irradiation } \\
\text { Temperature } \\
\left({ }^{\circ} \mathbf{C}\right)\end{array}$ \\
\hline FCAT-01 & 548 & $1.10 \times 10^{15}$ & $2.17 \times 10^{21}$ & $9.8 \times 10^{-7}$ & 1.9 & $200^{*}$ \\
\hline FCAT-02 & 548 & $1.04 \times 10^{15}$ & $2.05 \times 10^{21}$ & $9.3 \times 10^{-7}$ & 1.8 & $363.6 \pm 23.1$ \\
\hline FCAT-03 & 548 & $1.10 \times 10^{15}$ & $2.17 \times 10^{21}$ & $9.8 \times 10^{-7}$ & 1.9 & $559.4 \pm 28.1$ \\
\hline FCAT-04 & $2304 *$ & $1.10 \times 10^{15}$ & $8.68 \times 10^{21 *}$ & $9.8 \times 10^{-7} *$ & $7.6^{*}$ & $200^{*}$ \\
\hline FCAT-05 & $2304 *$ & $1.04 \times 10^{15}$ & $8.20 \times 10^{21} *$ & $9.3 \times 10^{-7} *$ & $7.2^{*}$ & $330^{*}$ \\
\hline FCAT-06 & $2304 *$ & $1.10 \times 10^{15}$ & $8.68 \times 10^{21} *$ & $9.8 \times 10^{-7} *$ & $7.6^{*}$ & $550^{*}$ \\
\hline FCAT-07 & $4608^{*}$ & $1.10 \times 10^{15}$ & $1.74 \times 10^{22 *}$ & $9.8 \times 10^{-7} *$ & $15.2^{*}$ & $200^{*}$ \\
\hline FCAT-08 & $4608 *$ & $1.04 \times 10^{15}$ & $1.64 \times 10^{22 *}$ & $9.3 \times 10^{-7} *$ & $14.4^{*}$ & $330^{*}$ \\
\hline FCAT-09 & $4608 *$ & $1.10 \times 10^{15}$ & $1.74 \times 10^{22} *$ & $9.8 \times 10^{-7} *$ & $15.2^{*}$ & $550^{*}$ \\
\hline
\end{tabular}

*Target values represented, nominal values are currently being determined

\subsection{Preliminary PIE}

The low dose $(<2$ dpa) samples have recently become available for PIE. Currently, the passive $\mathrm{SiC}$ thermometry is being analyzed to determine if the target irradiation temperatures have been met. Dilatometric analysis was conducted up to a maximum temperature of $600^{\circ} \mathrm{C}$ at a constant 
ramp rate of $1^{\circ} \mathrm{C} / \mathrm{min}$ and a cooling rate of $2.5^{\circ} \mathrm{C} / \mathrm{min}$ using a Netzsch $402 \mathrm{CD}$ dilameter. A standardized algorithm was used to determine the nominal irradiation temperatures [9]. To date, the FCAT-02 irradiation capsule has fully completed SiC dilaometric analysis, the FCAT-03 is partially completed and the FCAT-01 is awaiting analysis. Table 2 summarizes the completed analysis. Table 2 shows that the nominal average irradiation temperatures appear within $\sim 35^{\circ} \mathrm{C}$ of the specimen design temperatures for both the $330^{\circ} \mathrm{C}$ and $550^{\circ} \mathrm{C}$ irradiation capsules. As stated earlier, the $\mathrm{SiC}$ resides within in central portion of the capsule which is modeled to be the highest temperature regime. This would suggest actual irradiation specimen temperatures are much closer to the design temperatures.

Table 2: Results of dilatometric analysis of SiC thermometry bars contained within irradiated capsules.

\begin{tabular}{|c|c|c|c|c|c|}
\hline Capsule & Specimen & Minimum & Median & Maximum & $\begin{array}{l}\text { Average } \\
\text { Median }\end{array}$ \\
\hline \multirow[t]{2}{*}{ ID } & ID & Temperature & Temperature & Temperature & Temperature \\
\hline & & $\left({ }^{\circ} \mathrm{C}\right)$ & $\left({ }^{\circ} \mathrm{C}\right)$ & $\left({ }^{\circ} \mathrm{C}\right)$ & $\left({ }^{\circ} \mathrm{C}\right)$ \\
\hline \multirow{7}{*}{ FCAT-02 } & 14 TOP & 346.2 & 358.1 & 372.5 & \multirow{2}{*}{$370.6 \pm 17.6$} \\
\hline & 16 TOP & 359.9 & 383 & 405.7 & \\
\hline & $18 \mathrm{MID}$ & 336.4 & 345.2 & 368.2 & \multirow{2}{*}{$364.9 \pm 27.9$} \\
\hline & $20 \mathrm{MID}$ & 394.1 & 384.6 & 402.1 & \\
\hline & $22 \mathrm{BOT}$ & 337.9 & 329.5 & 342.4 & \multirow{2}{*}{$355.5 \pm 36.7$} \\
\hline & $24 \mathrm{BOT}$ & 369.9 & 381.4 & 403.1 & \\
\hline & Average & \multicolumn{4}{|c|}{$363.6 \pm 23.1$} \\
\hline \multirow{5}{*}{ FCAT-03 } & 26 TOP & 450.1 & 524.3 & 571.5 & \multirow{2}{*}{$556.7 \pm 45.8$} \\
\hline & 28 TOP & 635.0 & 589.1 & 601.1 & \\
\hline & 30 MID & 517.7 & 551.0 & 574.5 & 551.0 \\
\hline & $34 \mathrm{BOT}$ & 488.4 & 573.1 & 597.6 & 573.1 \\
\hline & Average & \multicolumn{4}{|c|}{$559.4 \pm 28.1$} \\
\hline
\end{tabular}

A single tensile specimen of 125YF from FCAT-01, FCAT-02, and FCAT-03 have been mechanically tested using uniaxial tensile tests to evaluate the mechanical performance of the alloy after irradiation. Tensile tests were completed using an Instron universal test machine with a crosshead speed of $0.0055 \mathrm{~mm} / \mathrm{s}$ resulting in a nominal strain rate of $\sim 10^{-3} \mathrm{~s}^{-1}$. No contact or non-contact extensometery was completed at the time of the test. All tests were performed at room temperature in air. The resulting stress-strain curves from these tests are shown in Figure 3. Yield strengths were found to be between 1037 and $1108 \mathrm{MPa}$. The $330^{\circ} \mathrm{C}, 1.8 \mathrm{dpa}$ and the $550^{\circ} \mathrm{C}, 1.9 \mathrm{dpa}$ specimens showed reasonable uniform elongations and total elongations with values at $5-6 \%$ and $9-12 \%$, respectively. Low temperature irradiations at $220^{\circ} \mathrm{C}$ resulted in higher embrittlement with an almost complete loss in work hardening and a total elongation of 5\%. The results shown in Figure 3 would suggest some degree of irradiation temperature dependence on the mechanical response of irradiated ODS FeCrAl alloys. Further PIE efforts, including advanced microstructural characterization, are needed to provide more insight on the radiation tolerance of this alloy class. 


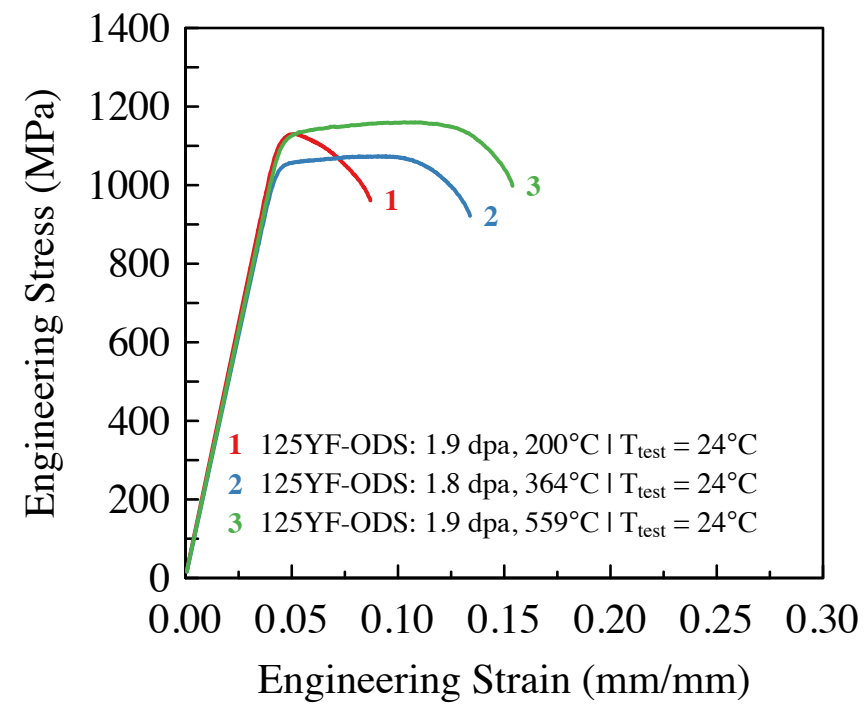

Figure 3: Plots showing representative stress-strain curves for the $125 \mathrm{YF}$ alloy after irradiation in the HFIR.

\section{FCAD IRRADIATION PROGRAM}

\subsection{Irradiation Capsule Design}

The same irradiation capsule design will be used for the FCAD series as the FCAT series in an effort to minimize cost and time to deployment. This capsule design is a very flexible design and can be loaded solely with SS-J2 tensile specimens, SS-2E tensile specimens, or a mixture of both. Here, it is planned to fill a capsule with solely SS-J2 sample geometries, resulting in 36 total specimens per irradiation condition. As discussed, the capsule also provides positions for passive SiC thermometry allowing for verification of irradiation temperature. The sub-assembly design, shown in Figure 4, has proven to be an effective design allowing for easy disassembly while in hot cell.

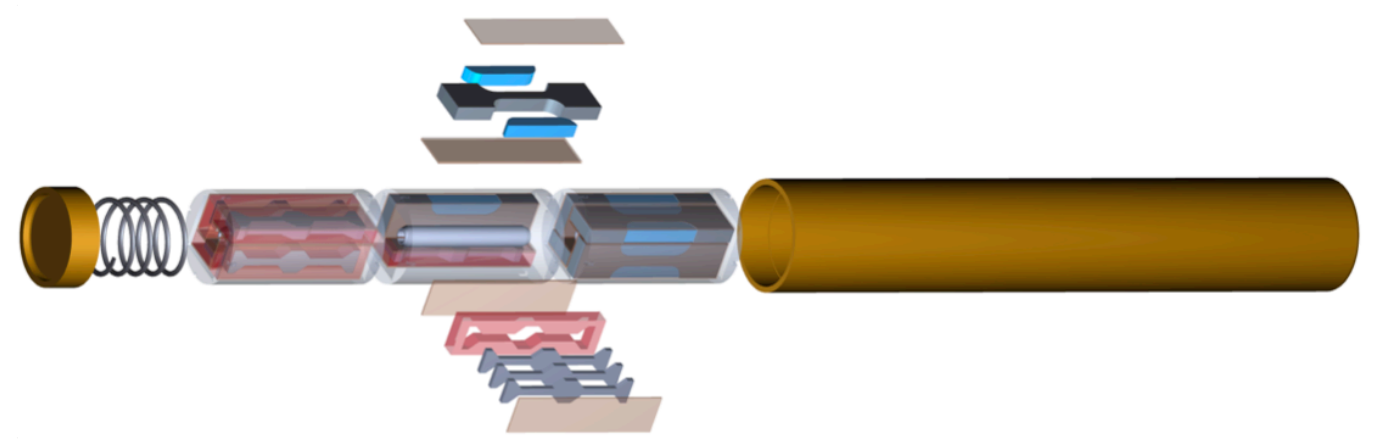

Figure 4: Finalized HFIR irradiation capsule design for FCAD irradiation program. Design is identical to the FCAT irradiation capsules. 


\subsubsection{Irradiation Test Matrix}

The test matrix has been developed to provide cross compatibility with irradiation conditions of the FCAY and FCAT irradiation programs [10] while also providing the high dose radiation response of these alloys. High dose responses are of interest as FeCrAl ODS alloys could have potential applications in other nuclear reactor designs such as fast reactors being developed by TerraPower, LLC. The proposed FCAD test matrix is provided in Table 3.

Table 3: Summary of FCAD irradiation test matrix.

\begin{tabular}{|c|c|c|c|c|c|c|}
\hline Capsule ID & $\begin{array}{c}\text { Exposure } \\
\text { Time } \\
\text { (hrs) }\end{array}$ & $\begin{array}{c}\text { Neutron Flux } \\
\left(\mathrm{n} / \mathrm{cm}^{2} \mathrm{~s}\right) \\
\mathrm{E}>0.1 \mathrm{MeV}\end{array}$ & $\begin{array}{c}\text { Neutron Fluence } \\
\left(\mathbf{n} / \mathrm{cm}^{2}\right) \\
\mathrm{E}>0.1 \mathrm{MeV}\end{array}$ & $\begin{array}{c}\text { Dose Rate } \\
\text { (dpa/s) }\end{array}$ & $\begin{array}{l}\text { Dose } \\
\text { (dpa) }\end{array}$ & $\begin{array}{c}\text { Irradiation } \\
\text { Temperature } \\
\left({ }^{\circ} \mathrm{C}\right)\end{array}$ \\
\hline FCAD-01 & 548 & $1.10 \times 10^{15}$ & $2.17 \times 10^{21}$ & $9.8 \times 10^{-7}$ & 1.9 & 330 \\
\hline FCAD-02 & 548 & $1.10 \times 10^{15}$ & $2.17 \times 10^{21}$ & $9.8 \times 10^{-7}$ & 1.9 & 550 \\
\hline FCAD-03 & 4384 & $1.10 \times 10^{15}$ & $1.74 \times 10^{22}$ & $9.8 \times 10^{-7}$ & 15.2 & 330 \\
\hline FCAD-04 & 4384 & $1.10 \times 10^{15}$ & $1.74 \times 10^{22}$ & $9.8 \times 10^{-7}$ & 15.2 & 550 \\
\hline FCAD-05 & 13152 & $1.10 \times 10^{15}$ & $5.21 \times 10^{22}$ & $9.8 \times 10^{-7}$ & 45.6 & 330 \\
\hline FCAD-06 & 13152 & $1.10 \times 10^{15}$ & $5.21 \times 10^{22}$ & $9.8 \times 10^{-7}$ & 45.6 & 550 \\
\hline
\end{tabular}

The alloy loading list is still in development. Currently, it is planned to use 14YWT as a reference material to the newly developed FeCrAl ODS alloys. It is also planned to include several Fe-12Cr ODS alloy variants to test the influence of $\mathrm{Al}$ and other alloying elements on the radiation tolerance of the alloys currently in development. Finally, several wrought FeCrAl alloys will be fielded to provide a contrast between the ODS and wrought alloy variants. At least 3 tensile specimens per alloy will be loaded per irradiation conditions resulting in 12 different alloys to be tested.

\subsubsection{Schedule}

The FCAD irradiation capsules are still undergoing final design and development. It is planned in U.S. fiscal year 2017 that samples and capsule internals will begin fabrication followed by inspection and final assembly. The lowest dose irradiation capsules will run for 1 cycle in the HFIR, while the 15.2 dpa will run for 8 cycles and the 45.6 dpa will run for 24 cycles. Insertion of capsules late in fiscal year 2017 would result in low dose capsules being ready for PIE in late 2017, early 2018 while the higher dose specimens will take an additional year and 3 years before PIE can begin. PIE for all capsules is planned to be similar to PIE already completed on the FCAY and FCAT irradiation capsules.

\section{REFERENCES}

[1] Y. Yamamoto, B.A. Pint, K.A. Terrani, K.G. Field, Y. Yang, L.L. Snead, Development and property evaluation of nuclear grade wrought $\mathrm{FeCrAl}$ fuel cladding for light water reactors, J. Nucl. Mater. 467 (2015) 703-716. doi:10.1016/j.jnucmat.2015.10.019.

[2] B.A. Pint, K.A. Terrani, M.P. Brady, T. Cheng, J.R. Keiser, High temperature oxidation of fuel cladding candidate materials in steam-hydrogen environments, J. Nucl. Mater. 440 (2013) 420 427. doi:10.1016/j.jnucmat.2013.05.047.

[3] S.J. Zinkle, L.L. Snead, Designing Radiation Resistance in Materials for Fusion Energy, Annu. 
Rev. Mater. Res. 44 (2014) 241-267. doi:10.1146/annurev-matsci-070813-113627.

[4] K.G. Field, X. Hu, K.C. Littrell, Y. Yamamoto, L.L. Snead, Radiation tolerance of neutronirradiated model Fe-Cr-Al alloys, J. Nucl. Mater. 465 (2015) 746-755. doi:10.1016/j.jnucmat.2015.06.023.

[5] P.D. Edmondson, S.A. Briggs, Y.Yamamoto, R.H. Howard, K. Sridharan, K.A. Terrani, et al., Irradiation-enhanced $\alpha^{\prime}$ precipitation in model FeCrAl alloys, Scr. Mater. 116 (2016) 112-116. doi:10.1016/j.scriptamat.2016.02.002.

[6] S.A. Briggs, P.D. Edmondson, Y. Yamamoto, C. Littrell, R.H. Howard, C.R. Daily, et al., A combined APT and SANS investigation of alpha prime phase precipitation in neutron-irradiated model FeCrAl alloys, Submitt. to Acta Mater. (2016).

[7] K.G. Field, R.H. Howard, Y. Yamamoto, Experimental Plan and Irradiation Target Design for FeCrAl Embrittlement Screening Tests Conducted Using the High Flux Isotope Reactor, Oak Ridge National Laboratory, n.d.

[8] S. Dryepondt, K.A. Unocic, D.T. Hoelzer, B.A. Pint, Oak Ridge National Laboratory Development of ODS FeCrAl Alloys For Accident-Tolerant Fuel Cladding, Oak Ridge, 2015. http://info.ornl.gov/sites/publications/files/Pub59171.pdf (accessed July 24, 2016).

[9] A.A. Campbell, W.D. Porter, Y. Katoh, L.L. Snead, Method for analyzing passive silicon carbide thermometry with a continuous dilatometer to determine irradiation temperature, Nucl. Instruments Methods Phys. Res. Sect. B Beam Interact. with Mater. Atoms. 370 (2016) 49-58. doi:10.1016/j.nimb.2016.01.005.

[10] K.G. Field, S.A. Briggs, P.D. Edmondson, J.C. Haley, R.H. Howard, X. Hu, et al., Database on Performance of Neutron Irradiated FeCrAl Alloys, Oak Ridge, TN, 2016. 